\title{
Resources, Capabilities, and Routines in Public Organizations
}

\author{
Peter G. Klein \\ Associate Professor, \\ Division of Applied Social Sciences, \& \\ Associate Director, Contracting and Organizations Research Institute \\ University of Missouri \\ 135 Mumford Hall \\ Columbia, MO 65211 \\ Phone: (573) 882-7008 \\ pklein@missouri.edu \\ Joseph T. Mahoney \\ Investors in Business Education Professor of Strategy, \& \\ Director of Graduate Studies, \\ Department of Business Administration \\ College of Business \\ University of Illinois at Urbana-Champaign \\ 1206 South Sixth Street \\ Champaign, IL 61820, USA \\ Phone: (217) 244-8257 \\ josephm@illinois.edu
}

Anita M. McGahan

Professor and Rotman Chair in Management

Rotman School of Management, University of Toronto

105 St George St

Toronto, ON M5S 3E6, Canada

Senior Institute Associate, Institute for Strategy \& Competitiveness, Harvard University

Fellow, AIC Institute for Corporate Citizenship

Phone: (416) 978-6188

amcgahan@rotman.utoronto.ca

\section{Christos N. Pitelis}

Director, Centre for International Business and Management

Judge Business School

University of Cambridge

Trumpington Street

Cambridge, CB2 1AG, UK

Phone: 44 (0) 1223339618

c.pitelis@jbs.cam.ac.uk

Copyright (C) 2010 Peter G Klein, Joseph T Mahoney, Anita M McGahan and Christos N Pitelis. All rights reserved. 


\title{
Resources, Capabilities, and Routines in Public Organizations
}

\begin{abstract}
States, state agencies, multilateral agencies, and other non-market actors are relatively understudied in strategic management and organization science. While important contributions to the study of public actors have been made within the agency-theoretic and transaction-cost traditions, there is little research in political economy that builds on resource-based, dynamic capabilities, and behavioral approaches to the firm. Yet public organizations can be characterized as stocks of human and non-human resources, including routines and capabilities; they can possess excess capacity in these resources; and they may grow and diversify in predictable patterns according to behavioral and Penrosean logic. This paper shows how resource-based, dynamic capabilities, and behavioral approaches to understanding public agencies and organizations shed light on their nature and governance.
\end{abstract}

\section{Keywords}

Resource-based view, dynamic capabilities, behavioral view, public organizations 


\section{Introduction}

That governments own and control valuable resources is so much a part of our daily discourse that we almost take it for granted. Analyses of taxation and government expenditures are as ubiquitous as taxation itself (Barzel, 1976; Kiesling, 1992; Samuelson, 1986). Typically, we think of governmental bodies controlling land, buildings, and budgets; yet government agencies, as organizations, control many kinds of valuable resources: infrastructure such as highways (Small \& Verhoef, 2007) and prisons (Hart, Shleifer \& Vishny, 1997), sensitive information about top-secret military activities (Vandenbroucke, 1993), knowledge systems such as rules of law (Tamanaha, 2005), and organizational assets such as the cultures of bureaucracy at established agencies (Peters, 2001). As a result, the fields of regulatory economics, antitrust analysis, law \& economics, political economy, and public administration all have their own specialized journals, societies, and academic programs.

Demand for insight about the nature and effective governance of public resources has never been greater. In the wake of the financial crisis and economic downturn, public and quasi-public entities such as credit-ratings agencies, the Federal Reserve System, Freddie Mac and Fannie Mae have been thrust in the spotlight (Brunnermeier, 2009; Cecchetti, 2008; Demyanyk \& Hemet, 2008). What were their roles in the housing bubble and bust (Coleman, LaCour-Little \& Vandell, 2008)? Did they fail to discharge their responsibilities? A US legislative effort to subject the Federal Reserve System to greater Congressional scrutiny brings many of these issues to the fore. Should central banks be "independent" -- mostly free from public and legislative oversight, constraint and sanction -- to exercise their functions adequately, or should they be subject to political or market discipline (Blei, 2009)?

The September 11, 2001 attacks raised similar questions about the US domestic security apparatus (Wise, 2002). Oliver Williamson's 2009 Nobel Lecture noted that the creation of the US Department of Homeland Security by consolidating formerly free-standing defense and intelligence services into a large, diversified organization is analogous to the formation of private conglomerates and other well-known kinds of business restructuring, and yet there was little analysis of the efficiency implication of the consolidation, despite decades of research on diversification and other resource and 
corporate consolidations. ${ }^{1}$ What are the consequences of integrating previously independent units with separate cultures, organizational forms, and mandates? How can the integration be optimized on both effectiveness in achieving goals and efficiency in achieving cost synergies? What kinds of innovation are enabled by the integration? What are the potential costs, including "big government" per se and its widely discussed downsides (Bacon \& Eltis, 1976; Feldstein, 1974; Wolf, 1993)?

Research in public and private administration has long acknowledged the central importance of resources in defining and shaping goals in the public sector. Allison's (1971) account of the Cuban missile crisis showed how military objectives are shaped by available resources and how these resources affected options, each with costs and risks. Baum and McGahan (2010) submit that current US and UK action in Iraq has been shaped in part by the conceptualization of military goals enabled by the deployment of private and public resources in tandem. During the Vietnam War, resource dependency and the bureaucracy of administration that accumulated around particular resources, so constrained strategic options that the US persisted even in the face of conditions that, had they been evident at the outset, might have deterred military action (Sheehan 1998). ${ }^{2}$

The current paper maintains that the field of organization science and strategic management can offer significant insights into the nature and effective and ineffective governance of public organizations. Public entities, like private firms, have been described using the language of entrepreneurship theory

\footnotetext{
${ }_{1}$ Agarwal, Barney, Foss and Klein make the same point about the government-led merger of Chrysler and Fiat: "The justifications for these actions are familiar to anyone who studies corporate strategy — the mythological search for synergy." But "[m]ost such corporate combinations - even those done voluntarily in non-crisis settings — fail to realize sought-for synergies" (2009: 474-475).

2 Allison (1971) notes that examination of bureaucracy in the Carnegie tradition (Cyert \& March, 1963; March \& Simon, 1958; Simon, 1947; Simon et al. 1950) - from which the current paper draws - is a linear descendent of the classic study of bureaucracy by Weber (1947), which explored the advantages of bureaucracy as an "ideal" type, emphasizing the rationalistic, impersonal, and specialized aspects of bureaucracy, as well as many of Weber's (1947) followers who presented the disadvantages of bureaucracy. Merton (1940) emphasized inefficiencies and dysfunctional aspects of bureaucratic impersonality when it crossed into rigidity - a theme highlighted in political science by Lindblom (1977) and in management by Leonard-Barton (1992). Selznick (1948) observed large and decentralized bureaucracies, and emphasized the problem created by divergent sub-goal pursuits, a decidedly Carnegie theme. Gouldner (1954) placed in the foreground the possibility that revealing explicit rules internally may lead to minimally acceptable behavior and thus decreased efficiency.
} 
(Klein, et al., 2010): governments, government agencies, social enterprises, charitable organizations, and other "non-market" decision-makers are alert to opportunities for value creation and capture, exercise judgment over the deployment of resources under uncertainty, and introduce technological and organizational innovations. Yet a central facet of public organizations that has not been studied comprehensively is the creation, stewardship, dynamics, and allocation of public resources and capabilities.

Important differences arise between public and private organizations relating to the definition and measurement of objectives, the ability to measure performance, and the role of governance. More generally, governments and government agencies transform resources into outputs and deploy the services of resources (Penrose, 1959) to achieve particular goals, which typically are not related to profitability, although they may be well expressed in terms of self-interested behavior. They play an important role in the allocation of resources. As such, one would expect organizational economics (Mahoney 2005) — including agency theory, transaction costs theory, property rights theory, the resource- based \& dynamic capabilities, and the behavioral approaches — to shed considerable light on the activities and performance of non-market decision makers (Baron, 1999; Hillman \& Hitt, 1999).

The organizational economics and strategic management literatures on the firm have devoted relatively little attention to the existence, boundaries, internal organization, growth, and performance of non-market organizations (Hill, Keim \& Schuler, 2004). Research in political science and public administration relies on terms such as "resources" and "transaction costs" and examines issues such as the growth of public agencies (Horn, 1995; Peters, 2005), but few studies in these fields build explicitly on concepts, theories, and models from organizational economics and firm strategy. In particular, while agency theory, and to a lesser extent transaction costs theory, have informed some research studies of public entities (Moe, 1993; North, 1990; Spiller \& Tommasi, 2003), the resource-based and dynamic capabilities approaches have rarely been employed (McWilliams, Fleet \& Cory, 2002; Oliver \& Holzinger, 2008). Surprisingly, the same holds for behavioral theories as inspired by the work of Simon (1947) and the Carnegie School. 
At first glance, this relative neglect is surprising: public organizations can be characterized as stocks of human and non-human resources, including routines and capabilities; they can acquire and/or develop excess capacity in these resources; and they may grow and diversify in predictable patterns partly in accordance with Penrose's (1959) logic. Importantly, ideas developed by Cyert and March (1963) and Simon (1947) are arguably at least as relevant for public organizations, as they are for private ones. In this sense, resource-based, dynamic capabilities, and behavioral approaches may provide additional insight on the nature, behavior, governance, and performance of public entities.

The current paper provides a critical review, synthesis, and reevaluation of the extant research literature on public organizations as firms, emphasizing contributions from economic and organizational theories of the firm, particularly the resource-based, dynamic capabilities, and recent behavioral approaches. We begin with a treatment of "public" resources, in the resource-based approach to the firm's sense of resources. What makes an opportunity, activity, or outcome "public" or "private"? What is the nature of public resources as distinct from private resources? Obviously some resources used by public actors - labor, buildings, office equipment, and human capital — have private market values, such that use by public actors carries an opportunity cost; moreover, public entities must (usually) compete with private entities for the use of these resources. Other resources either cannot or are not used privately and have no market values in this sense. Objectives and constraints can differ greatly between market and non-market actors (Bonardi, Hillman \& Keim, 2005; Bonardi \& Keim, 2005; Hirschmann, 1982).

The next section applies the distinction between public and private resources to public agencies as firms. We show that resource-based, dynamic capabilities, and modern behavioral approaches to the firm have richer implications for public policy than the perspectives of neoclassical economics, agency theory, and transaction costs theory. For example, we maintain that many state agencies have grown by a logic that is explicated in terms of a synthesis of behavioral and Penrosean ideas.

The third and final major section suggests that applying current theory to public-sector challenges in resource development, capability-building, and the cultivation of knowledge and behaviors - noting the ways in which these resources may develop over time - could substantially improve the efficacy of 
public administration. Recent developments in the organization and strategy fields regarding the identification of resource value open a window on issues of public importance, where organizational performance is intractably difficult to evaluate. We now know a great deal about how to identify and assess the value of private-sector resources, and by extending this insight to the public sector, we offer a perspective on how publicly owned resources are effectively managed.

\section{The resources and capabilities of public organizations}

Critical to resource-based, capabilities, and behavioral approaches to organizations is the concept of resources. Public organizations such as government bodies, multilateral agencies (such as the United Nations and World Health Organization), and informal actors produce "public" outputs — i.e., they do not buy and sell their products on the market, relying on financial measures of firm and business-unitlevel performance (Mises, 1944) — while using both public and private inputs. But what exactly are "public" resources? How do they differ from "private" resources (e.g., can they be characterized in terms of uniqueness, inimitability, and divisibility)? What do these differences imply about how resources are acquired - i.e., are there strategic factor markets (Barney, 1986) for collectively owned, politically controlled resources — and how are they combined and re-combined (Maritan \& Florence, 2008)?

Answers to these questions rest in part on a conceptualization of what constitutes the appropriate scale or unit of analysis for understanding public actors. Should the focus be on communities, village and city governments, states \& provinces, national governments, or multinational authorities? We take on the challenge by first acknowledging the importance of interactions between governmental authorities at each level: just as scholars currently study small, large, and multinational firms and the interactions between them, so should we study public agencies with various spans of authority and interactions between them. Second, we define public agencies without having to refer to the "public interest," which we view as multi-faceted, frequently changing, and difficult if not impossible to define (Arrow, 1951). Third, we confine our attention to public agencies that "own" and control resources either formally or informally. Many of the agencies that we examine have constitutional, legislative, or other formal authority to create 
resources through the levying of taxes or the accrual of fees through some well-defined mechanism, although some do not. What distinguishes the agencies that we study is their stewardship over resources that are not under the exclusive control of any other private or public actor. In other words, to qualify as a subject of our study, an organization must be a collective of some kind and must possess decision rights over the governance of resources (Olson, 1965). We turn first to theory for greater clarity in definitions of public resources. We then explore the relationships between public resources and public organizations, and finally turn in this section to questions about how public resources are governed.

\subsection{The nature of public resources}

Consider the very idea of public resources. "Public" in this context cannot mean simply “collectively owned," as many, if not most, private resources are owned or controlled by groups (shareholders, partners, family members). It also cannot refer to a resource's public-goods characteristics (nonexcludability and non-rivalry in use) because private organizations rely critically on resources that are at least partly public goods, such as knowledge, reputation, and goodwill. Hence a meaningful definition must distinguish between market and non-market ownership and control: private resources, in other words, are owned or controlled by identifiable individuals or groups operating in a voluntary, market setting, while public resources are owned by states that have the ability to use legally sanctioned coercion to acquire and deploy them. ${ }^{3}$

How are public resources valued? Public organizations own or control private resources, which are acquired in factor markets and have market values (land, buildings, inventory, IT systems, lobbying skills, and reputation) (Austen-Smith, 1993; Besley \& Coate, 2001; de Figueiredo \& Kim, 2004). However, other resources owned or controlled by public organizations do not have private value, either because they have no private analogue or because they cannot be used privately (e.g., military resources and physical infrastructure that could not also be put to private use). Public entities may also own or

\footnotetext{
${ }^{3}$ There are nuances, as private firms may obtain and use resources by state favor, and grant of privilege. Legal and political rules define and enforce the system of property rights, within which private ownership is exercised, so even "private" resources may rely on "public" elements for their existence and protection.
} 
control resources that have supra-private value; in other words, the value of the resource would be misstated by its private analogue either because of commons problems or because the public nature of the resource cannot be valued privately. For these reasons, valuing public resources is difficult.

One approach under the resource-based view is to characterize resources as valuable, rare, inimitable, and non-substitutable (VRIN) (Barney, 1991). The VRIN criteria yield insight about the existence of sources of potential competitive advantage within firms, and are analogous in the public domain to the emergence, boundaries, and growth of assets within a public jurisdiction that must compete for decision rights with other agencies that may seek to control resources similarly. VRIN criteria are most relevant in explaining why a state might have emerged to start with — by means of protecting VRIN resources from being usurped by rival groups-states (North, 1990). Moreover, the control of property rights over VRIN resources by state functionaries will have important implications for transaction costs, taxes accruing to the principal, and intra-national competition to control them. In addition, the development and leveraging of VRIN resources can be a potent source of competitive advantage for nations (Porter, 1990).

The sustainability of competitive advantage in the private sector has been associated with control over resources that are (a) difficult to transfer across organizations, often because of their intangibility (Itami \& Roehl, 1986); (b) inimitability; (c) non-substitutability; and (d) durability, which distinguishes resources from activities (Porter, 1991). In the public sector, strategically important resources have the same character: They are durable assets, which are difficult to transfer between agencies, unique in some essential way and thus difficult to substitute in the achievement of the agency's mission. Sustainability criteria are particularly important to understanding the behavior of public agencies as bureaucracies that build a scaffolding of administrative structure on top of resources that may form the original basis of their charter. The effective deconstruction of the scaffolding requires careful examination of the underpinning resources so as not to dismantle valuable and important assets through the process.

Theories of appropriability in the private sector emphasize how strategically important resources yield competitive advantage for organizations. Mechanisms of appropriability fall into four categories: 
(a) complementarity, (b) property rights, (c) governance, and (d) embeddedness. Complementarity arises when an organization possesses multiple assets that in combination enable the achievement of goals and is directly analogous in the public sector to resource combination. Property rights relate to the ability of a controlling organization to exclude others from profiting from the deployment of a strategically important resource. In the public sector, the proprietary benefits in fulfillment of mission achieved through property rights are generally observable. Governance theories relate to the organization's ability to deploy resources more effectively and efficiently than potential rivals, and extend into the public domain. Finally, embeddedness in the private context relates to the ways in which an organization can build a cluster of activities and complementary resources around the strategically important resource, and thereby appropriate returns from the resource by making its extraction difficult or even impossible. Public agencies may appropriate benefits from resources through exactly this process.

In the analysis of private-sector resources, insight is often obtained by examining the interplay between the existence, sustainability, and appropriability of competitive advantage obtained by an organization through its access to resources. For example, some organizations that have achieved and sustained competitive advantage historically may no longer appropriate the advantage because of hazards that have developed dynamically. Alternatively, a mature organization may appropriate advantages from resources and thus sacrifice their sustainability. Examining public resources for their existence, sustainability, and appropriability benefits requires a detailed understanding of their characteristics.

\subsection{Public resources and public organizations}

While there is substantial scope for applying the resource-based approach to the public domain, we suggest that this approach can be usefully analyzed within the overall context of Penrose's (1959) resources approach, especially as it is linked to the behavioral view (Cyert \& March, 1963). This theoretical linkage is useful because in Penrose (1959), firms are conceived as bundles of resources that provide services to serve a particular objective. This conceptualization applies directly to public organizations, which are also resource bundles — the main difference being the objective. Unlike the 
private firm's focus on economic profits (or value capture), the objective of public organizations is meant to be the pursuit of the public interest (or value creation). This theoretical linkage has applications to the nature, growth, and boundaries of public organization, as well as the public-private nexus, both of which have been largely neglected in the research literature.

The current paper posits that all organizations and their constituent individuals aim to capture value from their actions, action potential, and value-creating advantages (Pitelis \& Teece, 2010). In the case of private firms, success takes the form of profit (or value capture). However, in order to capture value a private organization must often create it in the first place (Penrose, 1959). Similarly, a public organization purportedly aims to create value for the wider public interest. However, at the level of the individual, the public agency, and/or the state as a whole, some part of the created value needs to be captured. Such value capture can take the form of the re-election of the politician, the survival and growth of the public agency, and the raising of revenues through taxes by the state. In this context, the aim of the private sector is to appropriate created value, while the aim of public organization is to create appropriable value. The two objectives are closely related, but there are important differences and implications for issues such as growth, boundaries, internal decision-making and functions, and differential advantages derived from dynamic capabilities.

Despite increased interest in "hybrid" forms of organization, the treatment of intra-organizational decision-making is not in the foreground of transaction costs, resource-based, or dynamic capabilities approaches. They are, however, at the heart of the behavioral view (Cyert \& March, 1963; March \& Simon, 1958). Fundamental insights of the behavioral view relate to adaptive aspirations, adaptive expectations, attention, bounded rationality, information processing, inducement-contributions balancing of stakeholder interests, interdependence, organizational coalitions, organizational learning, resource allocations, routines, problemistic search (that is partly random, but not blind), slack-induced search, satisficing, sequential decision making, sub-goal pursuit, uncertainty avoidance, and the quasi-resolution of intra-firm conflict through the use of organizational slack (Cyert \& March, 1963; Ocasio, 1997; Simon, 1952, Thompson, 1967). In such an environment, human thinking is the most important resource, and 
organizational decision makers must be mindful of the scarcity of attention. In operations management terms the bottleneck is the brain. Simon notes the strategic implication: "An information-processing subsystem (a computer or new organization unit) will reduce the net demand on the rest of the organization's attention only if it absorbs more information previously received by others than it produces — that is, if it listens and thinks more than it speaks" (1982: 175).

Bounded rationality has several important consequences including (1) selective perception of information, (2) adaptive, sequential information processing, (3) mental effort that is reduced by heuristic procedures, and (4) a process of active reconstruction for memory (March \& Simon, 1958; Simon, 1982). Systematic biases result with insensitivity to prior probability of outcomes, insensitivity to sample size, misconception of chance, failure to recognize regression to the mean, illusory correlation, insufficient adjustment and anchoring, and biases in the evaluation of conjunctive and disjunctive events (Kahnemann, Slovic \& Tversky, 1982). Given these biases, the behavioral approach considers the organization as an adaptive response to uncertainty and bounded rationality, and a vast (and more efficient) information processor than any given individual. Further, the main effect of the information and communications technology revolution has been to make capacity for attention rather than information the critical scarce resource in most organizational (and personal) decision making (Ocasio, 1997; Simon, 1982). Indeed, information is what consumes attention, frequently resulting in information overload.

These ideas concerning organizational capabilities apply even more strongly to public organizations than to private firms. Capabilities are programmatic, typically have elements of tacit knowledge, and are largely embedded in organizational routines (March \& Simon, 1958). These routines serve several important functions, including organizational memory as organizations remember by doing (Nelson \& Winter, 1982), and are facilitated by common language and coding (Arrow, 1974). Routines can also serve as a truce in inter-organizational conflict to maintain internal political stability, which enhance the efficacy of organizational slack (Cyert \& March, 1963).

There are synergies between Penrose (1959) and Cyert \& March's (1963) behavioral approach. In Penrose's (1959) theory of firm growth, slack is endogenous. It arises because specialization, learning by 
doing, and intra-firm knowledge creation and innovation lead to an excess capacity of resources. Entrepreneurial managers in pursuit of profit aim to leverage these resources for the purpose of value capture (profit). In this sense, innovation induces slack, which motivates further innovation (Pitelis, 2007). The absence of a direct profit motive in public organization breaks this positive loop since (emergent or intended) slack need not engender appropriable innovation. Instead, it is more likely to be used for the purposes of intra-organizational conflict alleviation (Cyert \& March, 1963). The growth of public organization in this context serves uncertainty avoidance more than risk taking and value capture strategy.

The nearest analogue to the profit motive of public organization is the collection of taxes. Taxes can help satisfy all the multivariate objectives of state functionaries, be they re-election, private benefit, and quasi-conflict resolution. Considering that public organization per se is not meant to be a profit making entity, the question emerges as to how it can best create the conditions for the maximum possible revenue of the state (in the form of taxes) to be assembled.

The concepts of absorptive capacity and differential dynamic capabilities and advantages (Penrose, 1959; Cyert \& March, 1963; Cohen \& Levinthal, 1990; Dosi et al., 2000, 2008; Nelson \& Winter, 1982; Teece, Pisano \& Shuen, 1997) are important in this context, as are the concepts of market extension (Olson, 2000), market creation (Casson, 2005) and market co-creation (Pitelis \& Teece, 2010). Olson (2000) employed the concept of market extension to explain how states can raise more revenues, not only by minimizing transaction costs and attenuating conflict, but also by creating value proactively. The emphasis on market extension-derived value creation extends North's (1990) work and suggests that public organizations can help extend existing markets through requisite actions. In the private entrepreneurship literature, Casson (2005) maintains that private entrepreneurs and firms can create markets. Pitelis and Teece (2010) go further in positing that market and value co-creation are important means through which entrepreneurs can achieve their value capture objectives. In this framework, (private) organization helps effect this co-creation, in tandem with customers, suppliers, competitors, and other stakeholders participating in this value creation process, including public organization and the state. 
The concept of market and value co-creation shows how public organizations and the state as a whole can help enhance overall value creation, which, indeed is the pool of prospective taxes. In this context, market and value co-creation can be seen as an important vehicle through which the state can achieve its complex objectives, all served by the raising of taxes. The concept of market and value cocreation has affinity to, but also extends and operationalizes, Ostrom's (1990) focus on institutional and organizational complementarities. While laudable, and supported by evidence, Ostrom's (1990) view gives insufficient attention to issues of agency and differing objectives and conflicts. These issues are central to agency and behavioral approaches. Market and value co-creation can help satisfy mutual public and private objectives while simultaneously providing the slack for requisite innovation by the private (value creation) and conflict alleviation (distribution) by the public.

Market and value co-creation involves absorptive capacity, dynamic capabilities, and differential advantages, and requires the establishment of legal frameworks, as well as the allocation and re-allocation of property rights to help co-create markets that can capture as much appropriable value as possible. Markets with existing VRIN-type resources and/or with a promise to develop such resources could be a candidate. Their selection by the state requires knowledge, as well as appropriate organization and incentive structures that filter and frame decision making processes (Tsoukas, 2009). It requires that public agents and public entrepreneurs (Klein et al., 2010) aim to capture as much as possible out of value brought about through market and value co-creation. As private firms too aim to capture value engendered through market and value co-creation, this approach brings closer the aims of public and private actors. At the same time, it is based on the existence of different comparative advantages; the private sector in the setting-up of organizations (firms) that help co-create markets and value, the public sector in facilitating that process through the reduction of transaction costs, the extension of markets, and the co-creation of markets and value. Both public and private organization requires legitimization, intrafirm conflict resolution, ideology, and leadership. They are, however, applied in different domains, intrafirm and intra-society respectively. This difference in domain also points to the different and requisite (dynamic) capabilities of private entrepreneurs versus public entrepreneurs. 
Leveraging modern developments in organization and strategy can build upon and extend insights from economics, law, and political science by emphasizing the requisite capabilities of private and public entrepreneurs and highlighting the coordination and management of market and value co-creation. This market and value co-creation framework differs from extant views on the nature, growth, and boundaries of comparative economic organization. We maintain that market co-creation is an underpinning raison d'être of both private and public organization. It also helps explain the growth and evolution of privatepublic interaction, which is becoming increasingly sophisticated in a knowledge-based, semi-globalized economy that requires resources, knowledge, and capabilities for market co-creation. The boundaries between public and private are predicated not only on dynamic transaction costs (Langlois, 1992), but also on differential (dynamic) capabilities in setting-up private organizations for the purpose of value capture through market and value co-creation (by private agents). Our approach also emphasizes the definition, protection, re-allocation, and distribution of property rights and the provision of institutional frameworks, mental models, and incentives that help co-create markets and appropriable value, a share of which is acquired (by public organizations) as taxes. Learning how to manage public and private market and value co-creation to mutual advantage, and creating incentive and organizational structures to do so, will partly determine the competitive advantage of nations.

\subsection{Governance of public resources}

Given that most publicly-owned resources are also partially owned privately, how should governance decisions be made? As public interests change how should public ownership of resources change? How should public agencies govern private resources that impinge on the public interest? How should resources that arise at multiple levels of government be coordinated? As noted above, public and private actors often compete in the same factor markets, even if public organizations do not sell their output in markets. Moreover, public officials, like corporate managers, do not own the resources they acquire and deploy but act as stewards on behalf of ultimate owners. As in the corporate governance literature, this relationship suggests potential agency problems such as the overuse or misuse of resources. While 
strategy and organization scholars are familiar with control mechanisms used by shareholders to limit managerial discretion in corporations, the research literature on governance and control of states and state agencies is not generally taught in business schools or given a prominent place in management research.

Klein et al. (2010) discuss some problems faced by non-market organizations in limiting discretionary behavior by state functionaries. Non-market decision makers operate in a more complex, and typically weaker, selection environment than private firms. Objectives are complex and ill-specified, performance targets are difficult to formulate, and feedback may be indirect. This ambiguity suggests the importance of administrative procedures to discourage rent-seeking.

We suggest here that insights from organization theory and behavioral science provide significant insight into these governance issues. Organization theory, while significantly developed in the field of public organization, has not been applied as extensively to the administration of particular resources per se. Consider, for example, public resources such as those deployed in banking systems, military initiatives, large-scale humanitarian relief actions, and major infrastructure projects. Major resources may include, respectively, the public trust, authority to challenge a sovereign, an airport such as at Port-AuPrince in Haiti, and the international air traffic control communication system. The creation, preservation, deployment and enhancement of each of the resources may involve interaction between many public and private actors, each with overlapping but distinctive agendas. Examining the legitimacy, status, and agency of each type of organization in the governance of resources carries the promise of yielding important insights for understanding how resources are effectively and efficiently managed.

Bounded rationality also affects the way organizations govern resources. Organizational defenses (Argyris, 1990) and groupthink (Janis, 1972) describe two dysfunctional governance processes that may emerge as public actors with access to strategically valuable resources seek to deploy them in situations of goal ambiguity and conflict. Allison's (1971) third interpretation of the Cuban missile crisis describes competing psychological profiles of critical decision makers as powerful determinants of their positions regarding resource allocation. Further research on governance under conditions of bounded rationality is needed to develop principles for evaluating administrative structures as stewards of critical resources. 


\section{Public organization as resource administration}

How can we move from the notion of public resources to a resource-based, capabilities, and behavioral approach to public organizations? By analogy, consider economic theories of the firm. Economists since Adam Smith (1776) have written about the effects of state action on business activity, but the application of economics and management theories to non-market organizations is a more recent phenomenon (e.g., Buchanan \& Tullock, 1962; Riker, 1962; Riker \& Ordeshook, 1973). Public choice economics and positive political theory model political actors with the same tools used by economists to model market actors: preferences, constraints, exchange, and equilibrium. The emerging field of "nonmarket strategy" (de Figueiredo, 2009; Shughart \& Razzolini, 2003) treats campaign finance, lobbying, litigation, and other political and legal activity as integrated elements of firms' strategies for value creation and capture (Grossman \& Helpman, 2001; Schuler, Rehbein \& Cramer, 2002).

\subsection{Neoclassical and transaction costs perspectives}

Neoclassical economics tends to explain public organization in terms of market failure and with an eye to supporting the first fundamental theorem of welfare economics (Dasgupta, 1986). Early treatments focused on defense, the provision of justice, and public works, to justify the existence of the state (Mueller, 2003). The market failures approach has subsequently been developed to include “imperfect" market structures (such as monopoly) and other types of externalities. Coase's (1960) logic focused on the "internalization of externalities," explaining hierarchical organization, both private and public, as a response to market failure resulting from high transaction costs (Arrow, 1970; Coase, 1937, 1960). Coase also points out that: "we find a category 'market failure' but no category 'government failure.' Until we realize that we are choosing between social arrangements, which are all more or less failures, we are not likely to make much headway" (1964: 195). Williamson concurs, adding that "[hypothetical organizational] ideals are operationally irrelevant. Within the feasible subset, the relevant 
test is whether (1) an alternative can be described that (2) can be implemented with (3) expected net gains. This is the remediableness criterion" (1996: 210). ${ }^{4}$

Following similar logic, and building on Williamson (1975, 1996), this paper maintains that the public sector too is likely to be beset with bounded rationality, asset specificity, and opportunistic behaviors. This reasoning provides a transaction (organizational) costs explanation of "government failure" that helps complement more conventional public choice approaches (Mueller, 2003; Wolf, 1979). Government failures can be at least partially explained by the myopia, rigidity, and conflicting policies of government agencies, and by political forces that allow interest groups to influence elected and unelected officials to initiate and perpetuate inefficient policies that enable these interest groups to accrue rents (Datta-Chaudhuri, 1990; Wintson, 2006). Williamson's (1975: 118-122) focus on the limits of vertical integration in the private sector concerning internal procurement (logrolling), internal expansion, and program persistence biases apply even more strongly in the government sector. Seen in this light, the transaction costs approach is useful in explicating markets, private and public failures, and therefore, institutional failures, which enables a comparative assessment of imperfect (market, hierarchy, and governmental) alternatives. Transaction costs theory also predicts the boundaries of market, firm, and public organization in terms of relative transaction (versus organizational) costs. In so doing it also explains endogenously why all production is not organized through a huge integrated private firm, or by the state (central planning).

A few political scientists have incorporated transaction costs and concepts of bounded rationality, asset specificity, bilateral dependency, and the fundamental transformation (Williamson, 1985) into their analysis of political action and political institutions. Moe (1993), however, points out key differences between market and political organization that render the application of transaction costs theory to politics problematic. Moe's (1993) builds on the concepts of "political uncertainty" and "political compromise."

\footnotetext{
${ }^{4}$ Demsetz called the market-failures approach the nirvana fallacy: "The view that now pervades much public policy economics implicitly presents the relevant choice as between an ideal norm and an existing 'imperfect' institutional arrangement. This nirvana approach differs considerably from a comparative institution approach in which the relevant choice is between alternative real institutional arrangements" (1969: 1).
} 
The concept of political uncertainty suggests that within the political framework the government succeeds in "usurping the property rights of others" and therefore that economic choices by decision makers are different from those in the market. Under political uncertainty:

[Decision makers] would be concerned with more than simply making efficient choices about the use and disposition of their property. They would also be concerned with taking action to protect their rights from usurpation - and with making current choices about their property that recognize and adjust for the possibility that other actors might seize their rights to the property in the future (Moe, 1993: 123).

This reasoning does not simply imply a different setting in which transactions take place, but is more fundamental: it is "uncertainty about the very basis of all transactions" (Moe, 1993: 124). This political uncertainty requires considerations of the specific costs of political transactions.

Political compromise refers to the larger setting in which a transaction takes place. Any contract is the result of "bargaining and haggling" under which process the actors make a number of compromises in order to reach a mutually satisfying solution. But in politics "those who are able to exercise public authority can impose their preferred outcomes on everyone else" (Moe, 1993: 126), which means one party does not make compromises while the other is forced to make whatever compromises the party with authority requires.

Williamson (1999), by contrast, maintains that government and private action should be regarded as alternative modes of governance - virtually everything done by government could, in principle, be done, or has historically been done, by private actors — and thus transaction costs theory can shed light on the efficient governance modes for various transactions. For instance, transactions in the public sphere include procurement transactions which are "akin to those of make-or-buy" (Williamson, 1999: 319) and regulatory transactions that are "often beset with asset specificity" (1999: 320), which implies that transaction-cost reasoning is useful.

Williamson (1999) introduces a new key attribute in addition to asset specificity, uncertainty and frequency for public transactions: probity. Probity refers to the "loyalty and rectitude with which certain public transactions are to be discharged" (Ruiter, 2005: 292). Due to government embodying the public's authority, sovereign transactions require probity. Specific configurations of asset specificity, uncertainty, 
frequency, and probity determine the efficient choice of governance structure among market, private hierarchy or hybrid, and government (Williamson, 1999).

\subsection{Evolutionary and behavioral perspectives}

The transaction costs framework in its early incarnations was comparatively static, and thus less applicable to the growth and evolution of institutions. Later developments by North $(1981,1990)$ adopted an historical, evolutionary perspective while incorporating the view that the driving force of economic change is a dominant group of "principals," which is more akin to behavioral views and is absent from the early transaction costs approaches. On the basis of such innovations, North (1990) explained the state in terms of the pursuit by principals of increased wealth (to tax) though increased efficiency and reduced transaction costs. North (1990) noted, however, that the pursuit of systemic transaction costs reductions may be hindered by the principals' need to tax the emerging wealth efficiently. This objective leads to induced favors (transfers of property rights) to organized groups (such as monopolies), which North (1990) maintained would more easily be taxed. Accordingly, the principals' interests may differ from the interests of the system as a whole. This conflict could produce systematic inefficiencies. Moreover, the actions of the principals are constrained by competition from within (other potential principals) and without (rival states).

North (1990) synthesized transaction costs, public choice, property rights, and agency-based views in a path-dependent, evolutionary context. However, North (1990) remained firmly within the confines of economics and did not consider resource-based (dynamic) capabilities and behavioral views, currently of much interest within organizational science and strategic management, views that the current paper submits can offer fundamental insights to the debate.

Behavioral economics has experienced a renaissance in recent years (Frantz, 2009), with many applications to finance, but fewer to management and organization. An emerging behavioral literature sometimes termed "libertarian paternalism" — seeks to apply behavioral insights to the design of public policies (Ariely, 2008; Camerer et al., 2003; O’Donaghue \& Rabin, 2003; Thaler \& Sunstein, 2003, 
2008). This research literature suggests that private actors suffer from biases and cognitive limitations such as lack of willpower or self-control, status quo bias, optimism bias, and susceptibility to framing effects leading them to make decisions that are inconsistent with their own preferences. By making marginal changes to the options available to market participants ("nudges"), the private benefits and costs of various actions, and the informational environment in which choices are made, market participants can be led to make "better" choices without reliance on heavy-handed, top-down regulation.

As a few critics have pointed out, however, this research literature downplays the cognitive and behavioral limitations affecting policymakers. The most obvious is Hayek's (1945) "knowledge problem" which limits the ability of government officials to design effective paternalistic policies (Rizzo \& Whitman, 2009a). The well-known incentive problems under bureaucracy are relevant to paternalism as well (Glaeser, 2006). There is also what Rizzo and Whitman call the "slippery-slope" problem: the vulnerability of these proposals "to slippery slopes that can lead from modest paternalism to more extensive paternalism" (2009b: 667). This concern, in Penrose's (1959) terms, is with the growth and diversification of the paternalist policy-making apparatus. The idea of slippery slopes in policy design, fueled in particular by the cognitive and behavioral limits of the policymaking team, shares much with behavioral theories of firm growth.

More generally, behavioral considerations should be incorporated, along with informational and transaction cost problems, into comparative institutional analysis - not only the choice between markets, hierarchies, and hybrids (Williamson, 1996), but also the choice among public policies. On the one hand, the neoclassical welfare economics challenged by Coase (1960, 1964), Demsetz (1969), and the publicchoice approach did tend to present an unsophisticated view of state actors (e.g., portraying regulators as omniscient, benevolent social planners) (Backhouse \& Medema, 2006). On the other hand, the Chicago School approach while successfully challenging such an unsophisticated view, has received its own share of criticisms. For example, Eggertsson (1990) notes that Demsetz (1969) held an overly optimistic view that property rights would develop to internalize externalities when the gains of internalization became greater than the cost of internalization. Characteristic of this optimistic view, the formulation of decision 
making with regard to property rights is solely in terms of private benefits and private costs. This price theory approach, however, neither deals with the free-riding problems that plague group decision making nor attempts to model political processes.

In short, as applied to political action, neoclassical theories of the firm attempt to explain the "prices" and quantities of non-market transactions, agency-theoretic approaches focus on the incentives given to public bureaucrats, and transaction costs theory considers the make-or-buy decision and the efficient governance structures for various transactions. None of these approaches, however, addresses the political equivalent of sustained competitive advantage - why do some government bodies, bureaus, and agencies outperform others? Why do some survive, persist, expand, and diversify while others are absorbed by other agencies, dismantled, or radically restructured? Here we submit that resource-based, capabilities, and behavioral theories of the firm add significant insight. We elaborate on these implications in the next section.

\section{Implications and discussion}

How does an understanding of public entities help us design, position, and govern them better? What do resource-based, dynamic capabilities and behavioral approaches say about the boundaries and internal organization of public entities? Does framing public-policy problems in this way generate new insights, or does it simply re-label existing understandings?

\subsection{The nature and boundaries of public organizations}

The discussion in section 2.2 above on market co-creation suggests that private and public organizations, seeking to leverage the resources and capabilities they own and manage, evolve and interact in complex ways. The capabilities of legal and regulatory systems, for example, emerge and extend along with those of the industries they govern and regulate. A salient example is the allocation of the electromagnetic spectrum (Coase, 1959; De Vany et al., 1969; Faulhaber \& Farber, 2003). In most countries radio frequencies are owned, de jure, by the nation as a whole, and leased to private operators under public, regulatory supervision. Coase (1959) analyzed the nature, behavior, and efficiency consequences 
of the US Federal Communications Commission as the commercial radio industry was born. More recently, as the demand for spectrum allocation has grown dramatically, telecommunications regulators learned to use complex auction mechanisms in an attempt to allocate frequencies to their highest-valued users, with mixed results (Crampton \& Schwartz, 2000; Klemperer, 2002). Clearly, the capabilities (and limitations) of the regulatory apparatus emerged and expanded as the industry itself took shape, and has continued to evolve as the technology matured. Today, formal legal institutions are struggling to keep up with market and technological developments in the area of intellectual property (e.g., digital media). ${ }^{5}$

How can such processes of co-creation be managed or directed to minimize the harm from rentseeking, judicial and administrative error, regulatory capture, and regime uncertainty? We are unaware of any research examining this problem from a resource-based or dynamic capabilities perspective, and it seems like a promising opportunity for joint work by legal scholars, regulatory economists, and management scholars. More generally, researchers should look at the relationships among various levels of institutional and organizational activity, along the lines of the four levels suggested by Williamson (2000): embeddedness (informal institutions, customs, traditions, norms, and religion), the institutional environment (formal rules of the game such as property law), governance (the play of the game, as manifest in contracts and organizations), and resource allocation and employment (prices and quantities, and incentive alignment). Decisions about resource allocation, focusing on equating benefits and costs at the margin, are made moment-by-moment, while changes in governance, aiming to align governance structures with transactional characteristics, occur more slowly. Changes to, and the evolution of, the institutional environment and embedded norms take place even more gradually, and are (particularly in the case of embedded norms) typically the "spontaneous" result of unintended consequences. Research on public organizational capabilities must obviously take the time dimension into account.

Private firms evolve and adapt in response to changes in the institutional environment, in efforts to create and capture value. Evidence on firm boundaries, for example, suggests that firms internalize

\footnotetext{
${ }^{5}$ Even in the case of the spectrum, critics charge that an open-access, commons-based model (e.g., fee simple rules with easement provisions) could make better use of modern frequency needs and capabilities than the current exclusive-license property-rights model (Faulhaber \& Farber, 2003).
} 
transactions as a response to weaknesses in the institutional environment. In countries with stable legal institutions, relatively efficient courts, and reasonable default rules for contract terms, for example, contracts tend to be less complete. If contracting parties can trust the courts to fill in the gaps, why bother to write out every contingency? Likewise, if a country has an efficient external capital market, firms can be small and specialized, relying on the capital markets to allocate resources among business units, but if the external capital market performs poorly, diversified business groups may arise to utilize their internal capital markets (Khanna \& Palepu, 2000). However, Aggarwal, et al. (2009) find that firms tend to establish better mechanisms for corporate governance in countries that already have strong rules for investor protection, suggesting a complementary, rather than substitute, relationship between aspects of the institutional environment and firms' preferred institutional arrangements.

\subsection{Growth and governance}

As noted above, behavioral views of organizations emphasize adaptive expectations, bounded rationality, organizational learning, routines, problemistic and slack-induced search, satisficing, sequential decision making, uncertainty avoidance, and the quasi-resolution of intra-firm conflict through the use of slack. Higgs's (1987) analysis of the growth of government in the United States in the twentieth century illustrates many aspects of this framework. Higgs (1987) shows that many New Deal regulatory agencies were thinly disguised, quickly resurrected versions of similar, ostensibly temporary, agencies set up during World War I, enacting virtually identical policies. The labor-market provisions of the National Industrial Recovery Act (NIRA), for example, copied almost exactly the language of War Labor Board provisions from 1918, while other NIRA policies were copied from the War Industries Board. The New Deal's Reconstruction Finance Corporation was modeled on World War I's War Finance Corporation, while the Agricultural Adjustment Act of 1933 copied the Lever Act of 1917. Moreover, the expanded role taken on by the state during these periods remained largely in place once the crisis passed, leading to what Higgs (1987) terms a "ratchet effect." In the language of management theory, Higgs's (1987) general line of reasoning is that government officials (regulators, courts, and elected officials), as well as 
private agents such as business executives, farmers and labor unions develop capabilities in economic and social planning during particular crisis periods and that, due to indivisibilities and transaction costs, tend to possess excess capacity in periods between crises. To leverage this excess capacity, they look for ways to keep these "temporary" measures in place. ${ }^{6}$

As capabilities emerge and develop they may also be shared between private and public organizations, partly through the "revolving door" linking top-level management positions across government and corporate entities. Defense contractors, global construction firms, and private military companies whose senior leadership positions are occupied by former military and government officials are an obvious example. A 1971 congressional report on U.S. conglomerates described Litton Industries, then a major military contractor, as follows: "Sophisticated in the inter-relationships between the government and private sectors of commercial activities, Litton has sought to apply technological advances, novel management techniques, and system concepts developed in government business to an expanding segment of the commercial economy" (U.S. Judiciary Committee, 1971: 360) These "system concepts," of course, were the financial accounting and statistical control techniques pioneered by Litton CEO Tex Thornton in World War II, when he headed the "Whiz Kids" at the Army's Statistical Control group. Robert McNamara, his leading protégé, would then apply the same techniques to the management of Ford Motor Company, and later to the management of the Vietnam War. ${ }^{7}$

${ }^{6}$ Downs's $(1966,1967)$ influential analysis of bureaucracy emphasizes personnel dynamics, rather than the development of capabilities, as the driver of growth. Government agencies expand and contract, Downs $(1966,1967)$ maintains, in response to changes in public demands for their services. Because bureaucracies tend to concentrate decision authority at the top of the hierarchy, the personalities of top officials are particularly important, and periods of rapid growth tend to attract a disproportionate share of "climbers," those who particularly value power, income, and prestige. Led by climbers, " $t$ ] he bureau becomes continuously more willing and able to innovate and to expand its assigned social functions by inventing new ones or 'capturing' those now performed by other less dynamic organizations. Such further expansion tends to open up even more opportunities for promotion. This in turn attracts more climbers, who make the bureau still more willing and able to innovate and expand, and so on. Rapid growth of a bureau's social functions thus leads to a cumulative change in the character of its personnel, which tends to accelerate its rate of growth still further" (Downs, 1966: 19-20).

${ }^{7}$ On Litton see also Sobel (1984): 68-72. On the relationship between Thornton and McNamara see Shapley (1993) and Byrne (1993). 
How are these kinds of co-evolutionary processes best managed and governed? Can they be channeled into uses that create social value? Here the role of governance is particularly important. Penrose (1959) emphasized that competitive advantage is generated not by resources per se, but the services of those resources. The value of these services depends on the knowledge and effort of the firm's management team (Foss, et al. 2008; Kor, 2003). As Alchian and Demsetz put it: "efficient production with heterogeneous resources is a result not of having better resources, but in knowing more accurately the relative productive performances of those resources" (1972: 793). Performance can thus be improved not only by substituting resources, but by replacing the top-management team.

Governments and government agencies are often slow to change leadership, however. Elections take place at infrequent intervals; agency heads are sometimes removed for poor performance, but may be retained or replaced for political reasons. The creation of the US Department of Homeland Security as a recombination of the resources of seven previously existing, stand-alone agencies, mentioned above, provides an interesting case. Did this reorganization represent an efficient consolidation, exploiting scale and scope economies by using fixed factors more efficiently and reducing transaction costs among operating units, or was it a political response to a crisis that avoided replacing members of the appropriate top-management teams?

\subsection{Rules versus discretion}

Just as private organizations are characterized by both rules and actions — what Pentland and Feldman (2008) call "ostensive" and "performative" aspects, respectively, of routines — public organizations have both their official, stated rationales and purposes, and their de facto policies and procedures. To what extent should these policies and procedures be constrained to follow fixed, typically formal, guidelines, as opposed to granting latitude and autonomy to public agents? This question recalls the "rules versus discretion" debate in monetary economics: following fixed rules provides credibility but limits agents' ability to deviate from established procedures in extraordinary circumstances. In the last eighteen months, central-bank and treasury departments in the United States and European Union have 
assumed greatly expanded authority in response to the financial crisis (for example, the US Federal Reserve System's purchase of mortgaged-backed securities and other "toxic assets" from private financial institutions). Giving public agents the latitude to engage in performative routines that deviate from their ostensible mandates (or previously established, and hence expected, routines) raises challenging issues. ${ }^{8}$

\subsection{Privatization and quasi-privatization}

Consider, as another example, the placement of publicly owned resources such as prisons and military capability into the hands of private agents for stewardship and deployment (Avant, 2005; Baum \& McGahan, 2010; Cabral, Lazzarini \& Azevedo, 2009). Private actors may be able to lower the costs of deployment, but the resources may not be preserved or developed in the public interest. Therefore, there may be a conflict between preserving the resource's value in the public interest and deploying the resource in the public interest.

Theories of regulatory capture, regulatory agency, public efficiency, and project finance have dealt extensively with the hazards and opportunities in private administration. Yet the transfer of resources for private administration in the public interest is only one example of the ways in which private and public actors interact over critical resources. Opportunities for innovation through publicprivate partnerships, privatization, and public administration are sorely needed for addressing the publicpolicy that arise, for example, through the (temporary) public ownership of General Motors. What can the government accomplish in the stewardship of GM's resources that could not be accomplished when the firm was privately owned and managed? The deepest opportunities may reside in re-configurations of resources in pursuit of the construction of a national high-speed train system, or in the advanced of new standards for the promotion of highly-fuel efficient vehicles.

\footnotetext{
${ }^{8}$ Hayek (1960), in particular, maintained that public policy should be guided, wherever possible, by abstract, general rules, rather than discretionary procedures. On the tension between Hayek's (1960) emphasis on the rule of law and spontaneous order, see Daumann (2007).
} 


\subsection{Concluding Remarks}

The current paper posits that resource-based, dynamic capabilities, and behavioral approaches to applicable to the issue of the boundaries and governance of public organization and the public-private nexus. Indeed, some behavioral ideas may be even more relevant to public organization (March \& Olsen, 1996; Scott, 1995). The leveraging of comparative advantages by public and private actors in market and value co-creation can provide a framework on the nature and boundaries of comparative economic organization, while behavioral ideas can add value toward understanding how to govern these activities.

We emphasize that the next generation of research in the evolving science of organization must go beyond unsophisticated views of state actors on the one hand, and overly optimistic views of property rights evolving toward efficiency via private contracting on the other hand. One of the first steps required is to join private contracting models of property rights evolution with the interest-group theory of legislations and government --- what Eggertsson (1990) calls the interest group theory of property rights.

Finally, in terms of theory development, this paper extends resource-based theories of private competitive advantage to the public sector in terms of (a) identification of resources, (b) assessing the existence of strategic resources, (c) evaluating the sustainability of organizational advantage, and (d) assessing the appropriability of value by an organization. These extensions are summarized in Table 1. Furthermore, we claimed in this paper that the concept of market and value co-creation and the leveraging of resources and (differential) capabilities to effect this can, on the one hand, provide a novel explanation of the nature of the state and its growth, as well as the public-private nexus. On the other hand, behavioral ideas, such as bounded rationality, the absence of a clear objective function, and the use of slack in conflict resolution (as well as ways in which organizational and incentive structures emerge and can frame decisions and filter information) can help explain the failure of many public organizations to achieve more effectively sustainable value and market co-creation. The devising of governance structures to obtain this objective is, in our view, fundamental for efficient public governance, and the area in which most progress can be realized through the leveraging of organization science and strategy scholarship. We can and will do better. 


\section{REFERENCES}

Agarwal, R., J. B. Barney, N. J. Foss and P. G. Klein (2009), Heterogeneous resources and the financial crisis: Implications of strategic management theory. Strategic Organization 7: 467-484.

Aggarwal. R. I. Erel, R. Stulz and R. Williamson (2009). Differences in governance practices between U.S. foreign firms: Measurement, causes, and consequences. Review of Financial Studies, 22: 3131-3169.

Alchian, A. A. and H. Demsetz (1972). Production, information costs, and economic organization. American Economic Review, 62: 777-795.

Allison, G. (1971). The Essence of Decision. Boston, MA: Little, Brown \& Company.

Argyris, C. (1990). Overcoming Organizational Defenses: Facilitating Organizational Learning. Needham, MA: Allyn \& Bacon.

Ariely, D. (2008). Predictably Irrational, Revised and Expanded Edition: The Hidden Forces That Shape Our Decisions. New York, NY: Harper Collins.

Arrow, K. J. (1951). Social Choice and Individual V alues. New Haven CT: Yale University Press.

Arrow, K. J. (1970). The organization of economic activity: Issues pertinent to the choice of market versus non-market allocation. In R. H. Haveman \& J. Margolis (eds.), Public Expenditure and Policy Analysis, pp. 59-71. Chicago, IL: Markham.

Arrow, K. J. (1974). The Limits of Organization. New York, NY: W. W. Norton.

Austen-Smith, D. (1993). Information and influence: Lobbying for agendas and votes. American Journal of Political Science, 37: 799-834.

Avant, D. A. (2005). The Market for Force: The Consequences of Privatizing Security. Cambridge, UK: Cambridge University Press.

Backhouse, R. E. and S. G. Medema (2006). Public choice and the Cambridge School: A new view. Working paper, Department of Economics, University of Birmingham.

Bacon, R. and W. Eltis (1976). Britain's Economic Problem: Too Few Producers. London, UK: Macmillan.

Barney, J. B. (1986). Strategic factor markets: Expectations, luck, and business strategy. Management Science, 32: 1231-1241.

Barney, J.B. (1991). Firm resources and sustained competitive advantage. Journal of Management, 17: 99-120.

Baron, D. P. (1999). Integrated market and non-market strategies in client and interest group politics. Business and Politics, 1: 7-34.

Barzel, Y. (1976). An alternative approach to the analysis of taxation. Journal of Political Economy, 84: 1177-1197.

Baum, J. C. and A. M. McGahan (2010). Outsourcing war: The transaction cost dynamics of private military companies after the cold war. University of Toronto, Working Paper. 
Besley, T. and S. Coate (2001). Lobbying and welfare in a representative democracy. Review of Economic Studies, 68: $67-82$.

Blei, S. K. (2009). If the Fed becomes a super regulator, politicians would be its kryptonite. Federal Reserve Bank of St. Louis, The Regional Economist (January): 14-15.

Bonardi, J.-P. A. J. Hillman and G. D. Keim (2005). The attractiveness of political markets: Implications for strategy. Academy of Management Review, 30: 397-413.

Bonardi, J.-P. and G. D. Keim (2005). Corporate political strategies for widely salient issues. Academy of Management Review, 30: 555-576.

Brunnermeier, M. K. (2009). Deciphering the liquidity and credit crunch, 2007-2008. Journal of Economic Perspectives, 23: 77-100.

Buchanan, J. M., and G. Tullock (1962). The Calculus of Consent: Logical Foundations of Constitutional Democracy. Ann Arbor, MI: University of Michigan Press.

Byrne, J. A. (1993). The Whiz Kids: Ten Founding Fathers of American Business—and the Legacy They Left Us. New York, NY: Doubleday.

Cabral, S., S. Lazzarini and P.P. Azevedo (2009), "Private operation with public supervision: evidence of hybrid modes of governance in Brazilian prisons," Public Choice (forthcoming).

Camerer, C, S. Issacharoff, G. Loewenstein, T. O’Donoghue, and M. Rabin (2003), Regulation for conservatives: Behavioral economics and the case for "asymmetric paternalism." University of Pennsylvania Law Review, 151: 1211-1254.

Casson, M. (2005). Entrepreneurship and the theory of the firm. Journal of Economic Behavior and Organization, 58: 327-348.

Cecchetti, S. G. (2008). Crisis and Response: The Federal Reserve and the Financial crisis of 2007-2008. Cambridge, MA: National Bureau of Economic Research.

Coase, R. H. (1937). The nature of the firm. Economica, 4: 386-405.

Coase, R. H. (1959). The Federal Communications Commission. Journal of Law and Economics, 2: 1-40.

Coase, R. H. (1960). The problem of social cost. Journal of Law and Economics, 3: 1-44.

Coase, R. H. (1964). The regulated industries. American Economic Review, 54 (May): 194-197.

Cohen, W. M. and D. A. Levinthal (1990). Absorptive capacity: A new perspective on learning and innovation. Administrative Science Quarterly, 35: 128-152.

Coleman, M., M. LaCour-Little and K. D. Vandell (2008). Sub-prime lending and the housing bubble: Tail wags dog? Journal of Housing Economics, 17: 272-290.

Crampton, P. and J. A. Schwartz (2000). Collusive bidding: Lessons from the FCC spectrum auctions. Journal of Regulatory Economics 17: 229-252. 
Cyert, R. M. and J. G. March (1963/1992). A Behavioral Theory of the Firm, 2nd ed. Englewood Cliffs, NJ: Prentice Hall.

Dasgupta, P. (1986). Positive freedom, markets and the welfare state. Oxford Review of Economic Policy, 2: 25-36.

Datta-Chaudhuri, M. (1990). Market failure and government failure. Journal of Economic Perspectives, 4: 25-39.

Daumann, F. (2007). Evolution and the rule of law: Hayek's concept of liberal order reconsidered. Journal of Libertarian Studies, 21: 123-150.

de Figueiredo, J. (2009), Integrated political strategy. Advances in Strategic Management, 26: 459-486.

de Figueiredo, J. and J. K. Kim (2004). When do firms hire lobbyists? The organization of lobbying at the Federal Communications Commission. Industrial and Corporate Change, 13: 883-900.

Demyanyk, Y. and O. V. Hemet (2008). Understanding the subprime mortgage crisis. St. Louis, MO: Federal Reserve Bank of St. Louis, pp. 1-39.

Demsetz, H. (1969). Information and efficiency: another viewpoint. Journal of Law and Economics, 12: 1-22.

De Vany, A., R. Eckert, C. Meyers, D. O'Hara and R. Scott (1969). A property system for market allocation of the electromagnetic spectrum: A legal-economic-engineering study. Stanford Law Review, 21: 1499-1561.

Dosi, G., M. Faillo and L. Marengo (2008). Organizational capabilities, Patterns of knowledge accumulation and governance structures in business firms. Organization Studies, 29: 1165-1185.

Dosi, G., R. Nelson and S. Winter (Eds). (2000). The Nature and Dynamics of Organizational Capabilities. Oxford, UK: Oxford University Press.

Downs, A. (1966). Bureaucratic Structure and Decision Making. Santa Monica, CA: Rand Corporation.

Downs, A. (1967). Inside Bureaucracy. Boston, MA: Little, Brown \& Company.

Eggertsson, T. (1990). Economic Behavior and Institutions. Cambridge, MA: Cambridge University Press.

Faulhaber, G. R. and D. J. Farber (2003). Spectrum management: Property rights, markets, and the commons. In: L.F. Cranor and S.S. Wildman, (Eds.), Rethinking Rights and Regulations: Institutional Responses to New Communication Technologies, pp. 193-206. Cambridge, MA: MIT Press.

Feldstein, M.S. (1974). Social security, induced retirement, and aggregate capital accumulation. Journal of Political Economy, 82: 905-926.

Foss, N. J., P. G. Klein, Y. Y. Kor and J. T. Mahoney (2008). Entrepreneurship, subjectivism, and the resource-based view: Towards a new synthesis. Strategic Entrepreneurship Journal, 2: 73-94.

Frantz, R. (Ed). (2009). Renaissance in Behavioral Economics: Essays in Honour of Harvey Leibenstein. London, UK: Routledge.

Glaeser, E. L. (2006). Paternalism and psychology. University of Chicago Law Review, 73: 133-157.

Gouldner, A. W. (1954). Patterns of Industrial Bureaucracy. Glencoe, IL: The Free Press.

Grossman, G. and E. Helpman (2001). Special Interest Politics. Cambridge, MA: MIT Press. 
Hart, O., A. Shleifer and R. W. Vishny (1997). The proper scope of government: Theory and an application to prisons. Quarterly Journal of Economics, 112: 1127-1161.

Hayek, F. A. (1945). The use of knowledge in society. American Economic Review, 35: 519-530.

Hayek, F. A. (1960). The Constitution of Liberty. Chicago, IL: University of Chicago Press.

Higgs, R. A. (1987). Crisis and Levithan: Critical Episodes in the Growth of American Government. Oxford, UK: Oxford University Press.

Hillman, A. and M. Hitt (1999). Corporate political strategy formulation: A model of approach, participation and strategy decisions. Academy of Management Review, 24: 825-842.

Hillman, A. J., G. D. Keim and D. A. Schuler (2004). Corporate political strategies: A review and research agenda. Journal of Management, 30: 837-857.

Hirschmann, A. O. (1982). Shifting Involvements: Private Interest and Public Action. Princeton, NJ: Princeton University Press.

Horn, M. J. (1995). The Political Economy of Public Administration: Institutional Choice in the Public Sector. Cambridge, UK: Cambridge University Press.

Itami, H. and T. Roehl (1987). Mobilizing Invisible Assets. Cambridge, MA: Harvard University Press.

Janis, I. (1972). Groupthink. New York, NY: The Free Press.

Kahnemann, D., P. Slovic and A. Tversky (1982). Judgment under Uncertainty: Heuristics and Biases. Cambridge, UK: Cambridge University Press.

Khanna, T. and K. Palepu (2000). The future of business groups in emerging markets. Academy of Management Journal, 43: 268-285.

Kiesling, H. (1992). Taxation and Public Goods: A Welfare and Economic Critique of Tax Policy Analysis. Ann Arbor, MI: University of Michigan Press.

Klein, P. G., J. T. Mahoney, A. M. McGahan and C. N. Pitelis (2010), Toward a theory of public entrepreneurship. European Management Review.

Klemperer, P. (2002). Some observations on the British and German 3G Telecom auctions. ifo Studien, 48: $115-120$.

Kor, Y. Y. (2003). Experience-based top management team competence and sustained growth. Organization Science, 14: 707-719.

Langlois, R. N. (1992). Transaction-cost economics in real time. Industrial and Corporate Change, 1: 99-127.

Leonard-Barton, D. (1992). Core capabilities and core rigidities: A paradox in managing new product development. Strategic Management Journal, 13: 111-125.

Lindblom, C. E. (1977). Politics and Markets. New York, NY: Basic Books.

Mahoney, J. T. (2005). Economic Foundations of Strategy. Thousand Oaks, CA: Sage Publications Inc. 
March, J.G. and J.P. Olsen (1996). Institutional perspectives on political institutions. Governance, 9: 247-264.

March, J. G. and H. A. Simon (1958). Organizations. New York, NY: John Wiley \& Sons.

Maritan, C. A., and R. E. Florence (2008). Political activity as strategic factor market competition. Paper presented at the Strategic Management Society Conference, October, Cologne, Germany.

McWilliams, A., D. D. Fleet and K. D. Cory (2002). Raising rivals' costs through political strategy: An extension of resource-based theory. Journal of Management Studies, 39: 707-723.

Merton, R. K. (1940). Bureaucratic structure and personality. Social Forces, 18: 560-568.

Mises, L. v. (1944). Bureaucracy. New Haven, CT: Yale University Press.

Moe, T. M. (1993). The politics of structural choice: Toward a theory of public bureaucracy, in O. E. Williamson, Organization Theory: From Chester Barnard to the Present and Beyond, pp. 116-153. New York, NY: Oxford University Press.

Mueller, D. C. (2003). Public Choice. Cambridge, UK: Cambridge University Press.

Nelson, R. R. and S. G. Winter (1982). An Evolutionary Theory of Economic Change. Cambridge, MA: Harvard University Press.

North, D.C. (1981). Structure and Change in Economic History. New York, NY: Norton.

North, D.C. (1990). Institutions, Institutional Change, and Economic Performance. Cambridge, UK: Cambridge University Press.

Ocasio W. (1997). Towards an attention-based view of the firm. Strategic Management Journal, 18:187-206.

O’Donoghue, T. and M. Rabin (2003). Studying optimal paternalism, illustrated by a model of sin taxes. American Economic Review, 93: 186-191.

Oliver, C. and I. Holzinger (2008). The effectiveness of strategic political management: A dynamic capabilities framework. Academy of Management Review, 33: 496-520.

Olson, M. (1965). The Logic of Collective Action. Cambridge, MA: Harvard University Press.

Olson, M. (2000). Power and Prosperity. New York, NY: Basic Books.

Ostrom, E. (1990). Governing the Commons: The Evolution of Institutional Forms of Collective Action. Cambridge, UK: Cambridge University Press.

Penrose, E. T. (1959). The Theory of the Growth of the Firm. New York, NY: John Wiley \& Sons.

Pentland, B. T. and M. Feldman (2008). Designing routines: On the folly of designing artifacts, while hoping for patterns of action. Information and Organization, 18: 235-250.

Peters, P. G. (2001). The Politics of Bureaucracy. New York, NY: Routledge.

Peters, P. G. (2005). Institutional Theory in Political Science: The New Institutionalism. London, UK: Biddle, Ltd. 
Pitelis, C. N. (2007). A behavioral resource-based view of the firm: The synergy of Cyert and March (1963) and Penrose (1959), Organization Science, 18: 478-490.

Pitelis, C.N. and D, J. Teece (2010). Cross-border Market Co-creation, Dynamic Capabilities and the Entrepreneurial Theory of the Multinational Enterprise. Industrial and Corporate Change.

Porter, M. (1990). The Competitive Advantage of Nations. New York, NY: Free Press.

Porter, M. (1991). Towards a dynamic theory of strategy. Strategic Management Journal, 12: 95-117.

Riker, W. H., (1962). The Theory of Political Coalitions. New Haven, CT: Yale University Press.

Riker, W. H., and P. C. Ordeshook (1973). An Introduction to Positive Political Theory. Englewood Cliffs, NJ, Prentice-Hall.

Rizzo, M. J. and D. G. Whitman (2009a). The knowledge problem of new paternalism. Brigham Young University Law Review, 2009: 905-968.

Rizzo, M. J. and D. G. Whitman (2009b). Little brother is watching you: new paternalism on the slippery slopes. University of Arizona Law Review, 51: 685-739.

Ruiter, D. W. P. (2005). Is transaction cost economics applicable to public governance? European Journal of Law and Economics, 20: 287-303.

Samuelson, P. A. (1986). Theory of optimal taxation. Journal of Public Economics, 30: 137-143.

Schuler, D., K. Rehbein and R. Cramer (2002). Pursuing strategic advantage through political means: A multivariate approach . Academy of Management Journal, 45: 659-672.

Scott, W. R. (1995). Institutions and Organizations. Thousand Oaks, CA: Sage Publications.

Selznick, P. (1948). Foundations of the theory of organization, American Sociological Review, 13: 25-35.

Shapley, D. (1993). Promise and Power: The Life and Times of Robert McNamara. Boston. MA: Little, Brown.

Sheehan, N. (1988). A Bright and Shining Lie. New York, NY: Vantage, 1988.

Shughart, W.F., and L. Razzolini (2003). The Elgar Companion to Public Choice. Aldershott, UK: Edward Elgar.

Simon, H. A. (1947). Administrative Behavior. New York, NY: Macmillan.

Simon, H.A., D.W. Smithburg and V.A. Thompson (1950). Public Administration. New York, NY: Knopf.

Simon, H. A. (1952). A comparison of organization theories. Review of Economic Studies, 20: 40-48.

Simon, H. A. (1982). Models of Bounded Rationality: Behavioral Economics and Business Organization. Cambridge, MA: MIT Press.

Small, K. and E. Verhoef (2007). The Economics of Urban Transportation. New York, NY: Routledge.

Smith, A. (1776). An Enquiry into the Nature and Causes of the Wealth of Nations. The Glasgow Edition of the Works and Correspondence of Adam Smith. London, UK: Strahan \& Cadell. 
Sobel, R. (1984). The Rise and Fall of the Conglomerate Kings. New York: Stein and Day.

Spiller, P. T. and M. Tommasi (2003). The institutional foundations of public policy. Joumal of Law, Economics \& Organization, 19: 281-306.

Tamanaha, B.Z. (2005). On the Rule of Law: History, Politics, Theory. Cambridge, UK: Cambridge University Press.

Teece, D.J., G. Pisano and A. Shuen (1997). Dynamic capabilities and strategic management. Strategic Management Journal, 18: 537-533.

Thaler, R. H. and C. R. Sunstein (2003). Libertarian paternalism. American Economic Review, 93: 175-179.

Thaler, R. H. and C. R. Sunstein (2008). Nudge: Improving Decisions about Health, Wealth, and Happiness. New Haven, Conn.: Yale University Press.

Thompson, J. D. (1967). Organizations in Action. New York, NY: McGraw-Hill.

Tsoukas, H. (2009). A dialogical approach to the creation of new knowledge in organizations. Organization Science, 20: 941-957.

U.S. Judiciary Committee, Antitrust Subcommittee (1971). Investigation of Conglomerate Corporations.

Washington, D.C.: U.S. Government Printing Office.

Vandenbroucke, L. S. (1993). Perilous Options: Special Operations as an Instrument of U.S. Foreign Policy. Oxford, UK: Oxford University Press.

Weber, M. (1947). The Theory of Social and Economic Organization. Edited with and introduction by T. Parsons. New York, NY: The Free Press.

Williamson, O.E. (1975). Markets and Hierarchies: Analysis and Antitrust Implications. New York, NY: The Free Press.

Williamson, O.E. (1985). The Economic Institutions of Capitalism: Firms, Markets, Relational Contracting. New York, NY: The Free Press.

Williamson, O. E. (1996). The Mechanisms of Governance. New York, NY: Oxford University Press.

Williamson, O. E. (1999). Public and private bureaucracies: A transaction cost economics perspective. Journal of Law Economics \& Organization, 15: 306-342.

Williamson, O. E. (2000). The new institutional economics: Taking stock, looking ahead. Journal of Economic Literature, 38: 595-613.

Winston, C. (2006). Government Failure versus Market Failure: Microeconomics Policy Research and Government Performance. Washington, D. C.: Brookings Institution Press.

Wise, C. R. (2002). Organizing for homeland security. Public Administration Review, 62: 131-144.

Wolf, C. (1979). A theory of non-market failures: Framework for implementation analysis. Journal of Law and Economics, 22: 107-139.

Wolf, C. (1993). Markets or Governments: Choosing between Imperfect Alternatives. Cambridge, MA: MIT Press. 
Table 1: The extension of resource-based theories of private competitive advantage to the public sector

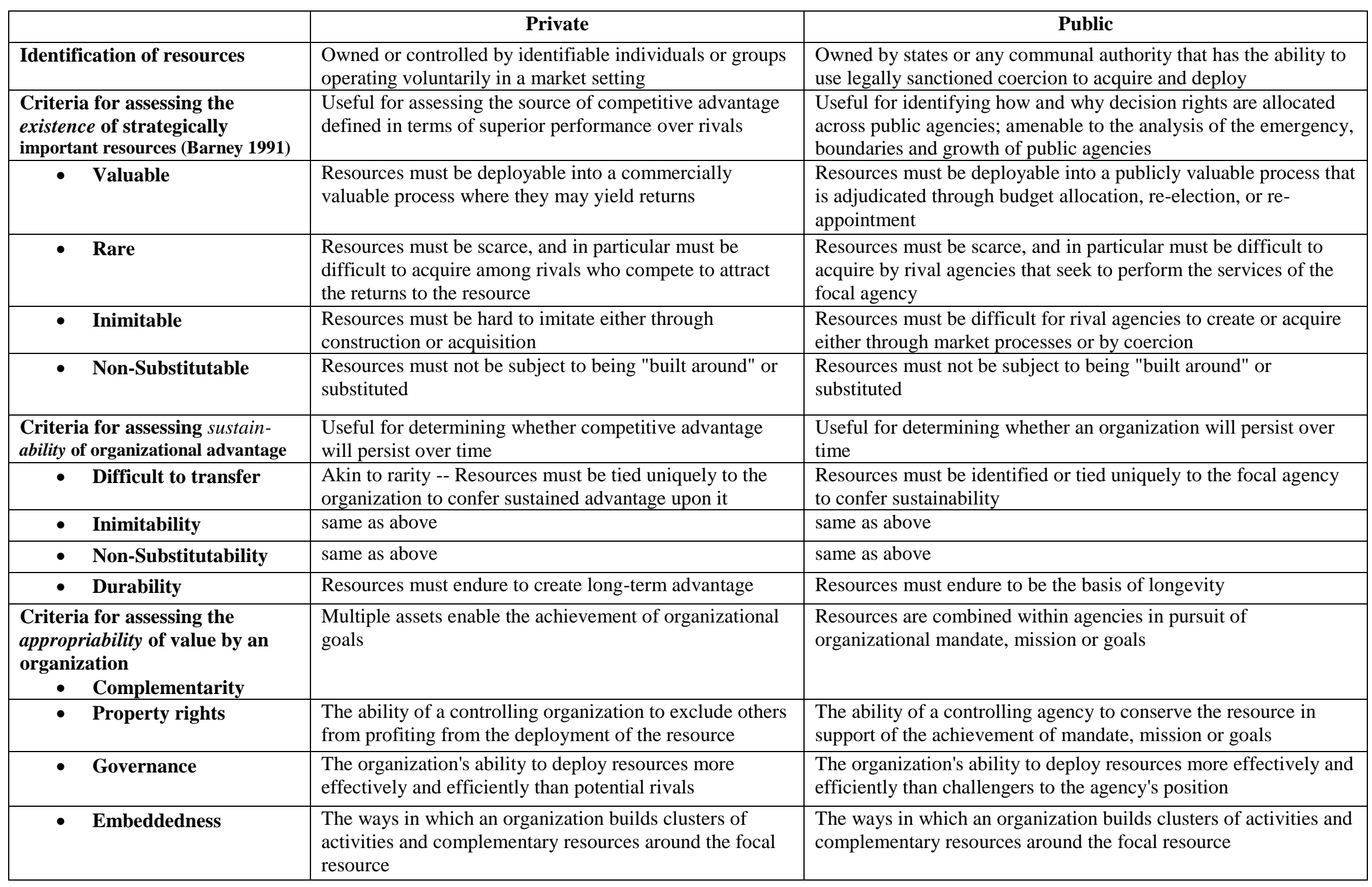

